\title{
ДИСКРИМІНАЦІЯ ЗА ВІКОМ (НА ПРИКЛАДІ КАЗУСІВ СВРОПЕЙСЬКОГО СОЮЗУ)
}

\author{
ГРЕНЬ Наталія Михайлівна - кандидат юридичних наук \\ https://orcid.org/0000-0001-5780-9423 \\ УДК 304.4 \\ DOI 10.32782/EP.2021.1.1
}

\begin{abstract}
Дискриминация по возрасту часто не в перечень основнылх нормативных признаков, однако сейчас оно занимает если не первое место, то входит в тройку лидеров по дискриминачионным признакам. Проблема такого вида дискриминации имеет двойной характер: ё̈ или не замечают, считая указанное нормальнълм, гуманнъим, жизненнълм развитием или наоборот вылеляют ее с другими видами дискриминации, в частности расовой, половой и другими. Стереотипь - это сочиальнье общие познания и предвзятье взглядъ и убеждения, которые не основываются на хорошо установленных фбактах. Возрастнъле стереотипь могут влиять на принятие решений, оценки и поведение членов организачии и препятствовать обработке новой инбормачии, противоречащей этим ошибочньлм убеждением. Таким образом, возрастнъие стереотипь могут повлечь дискриминационное поведение. Стереотипь по возрасту особенно поразительнъи и дискриминационныле. Старый человек -это всегда больное, требующее внимания и помощи лищо, тратит социальнье средства из государственного бюджета. Рассмотрение правовой политики ряда развитьхх стран (в частности Кипра и Чехии) указввает на наличие существеннъгх пробелов в правовом регулировании, которвие иногда оправдвиванотся бинансовой, правовой, соииальной и другими видами политики. Доказано, что больше всего проблем дискриминации по возрасту испьттьвают лица возрастной категории за 60 лет, и объгчно они касаются трудового и граж-
\end{abstract}

данско-пенсионного характера. Однако такой подход противоречит приниипу гуманности и равенства всех лии, поэтому обеспечение права на образование, свободное развитие, коммуникачию, мобильность и другие перечисленньие казусъ свидетельствуют о необходимости дополнительного юридического анализа проблематики.

Ключевъе слова: дискриминачия, дискриминация по возрасту, стереотип, Уполномоченный по правам человека, эйджизм, лица пожилого возраста.

\section{Постановка проблеми}

Як вказує I. Жаровська «етап демократичних перетворень в Україні характеризується загостренням політичних і соціальних суперечностей» $[1$, с.242], однією серед них є проблеми дискримінації. Її слід сприймати як розповсюджене (часто легітимізоване) порушення прав людини. За таких обставин особа зазнає ущемлення своїх конституційних, більше того природніх прав людини. Тому питання дискримінації за будь-якою $\mathrm{\epsilon}$ суттєвою проблемою людини, громади, держави, органів публічної влади та суспільства загалом.

\section{Стан дослідження}

Проблему належної реалізації прав та свобод піднімали українські дослідники, серед яких Ю. Бисага, Н. Бортник, І. Жаровська, Н. Оніщенко, А. Селіваном та інші відомі фахівці. Проте проблема дискримінації за віком нині не є поширеною науково-дис- 


\section{Теорія, історія держави і права, конституційне право}

кутованою проблематикою, тому потребує в національній правовій практиці окремої уваги.

Метою роботи $\epsilon$ аналіз правової проблеми дискримінації за ознакою віку на практиці низки рішень інституційних органів Европейського Союзу.

\section{Виклад основних положень}

Стереотипи - це соціальні спільні пізнання та упереджені погляди та переконання, які не грунтуються на добре встановлених фактах. Вікові стереотипи можуть впливати на прийняття рішень, оцінки та поведінку членів організації та перешкоджати обробці нової інформації, що суперечить цим помилковим переконанням. Таким чином, вікові стереотипи можуть спричинити дискримінаційну поведінку. Стереотипи за віком є особливо разючі та дискримінаційні. Стара людина -це завжди хвора, потребуюча уваги та допомоги особа, яка витрачає соціальні кошти з державного бюджету.

Проблеми дискримінації за віком нині є особливо проблемними. Расизм став актуальною проблемою в 19 столітті, і $з$ ним боролися активісти за громадянські права; сексизм став актуальною проблемою у 20 столітті, і його подолало виборче право та феміністичні рухи . Сьогодні дискримінація - це ейджизм. Її поширення є суттєвим. Більше того дискримінація за віком є дуже поширеним явищем незалежно від куточків планети та розвитку державності. Проблема полягає у латентності явища. Це не класичний вид латентності. Навпаки дискримінацію за віком не сприймають і не розуміють як таку плутаючи іiі з низкою інших дискримінаційних ознак. I як вказують іноземні дослідники, зокрема Дж. Крістіен [2] таУ. Менер [3] «хоча існують конкретні зусилля щодо зменшення расизму та сексизму, для зменшення ейджеїзму робиться дуже мало, оскільки його неявний характер ейджизму важко помітити».

Дискримінація за віком (так званий ейджизм) впливає як на молодих, так і на старих. Термін «ейджизм» вперше був використаний у 1969 році в СІІА Робертом Батлером (1927-2010), який був лікарем, а також першим директором Національного Інституту старіння.

Коли ейджизм був вперше визначений Батлером, явище розглядалось як щось, спрямоване лише на літніх людей, і характеризувалось негативною валентністю [4]. Сам Батлер у статті 2005 року пояснив, що, виходячи зі свого досвіду в 1968 році щодо ставлення громадськості до дорослих людей, він вирішив, що «упередження не відрізняються від дискримінації чорношкірих та жінок, що зазнають останні у суспільстві». Тому для нього термін ейджизм з'явився природним шляхом, оскільки інші групи населення страждали внаслідок того, ким вони були, тобто „ірраціональним упередженням” та „глибоким осудом з боку молодих та середніх років; особиста відраза та відраза до старіння, хвороб, інвалідності; і страх перед безсиллям, «марністю» та смертю»[5, р.14].

Однак згодом термін набув додаткового, поширеного значення. Подібним чином, ейджизм позиціоновано іншими як ставлення, дія чи інституційна структура, яка розглядає людину чи групу на основі ії віку як певну особливу або будь-який розподіл ролей у суспільстві через їх вік.

Явище ейджиїзму слід серйозно враховувати особам, що розробляють соціальну політику, для сприяння програмам соціальної інтеграції літніх людей. Уникнення заходів проти ейджизму може призвести до соціальної маргіналізації літніх людей, що може покласти величезні фінансові та соціальні витрати на місцеві економіки для вирішення таких питань, як погіршення психічного та фізичного здоров'я людей похилого віку внаслідок їх соціальної ізоляції. Дуже важливо вивчити наслідки ейджизму для людей похилого віку.

Проте, вагомо визначити, що правова політика вирішення глобальної проблеми загальнодержавного значення не завжди може містити елементи дискримінації за віком.

Для прикладу візьмемо політику Кіпру, яка у звітах міжнародних моніторингових груп часто отримуе схвальні відгуки. У практиці Кіпрського антидискримінаційного органу є права, щодо врахування критеріїв віку для надання субсидії при при- 
дбанні житла в районах 3 населенням до 200 мешканців, а точніше мінімальний вік 35 років, встановлений для самотніх людей, які бажають придбати будинок у згаданих районах. Скаржник стверджував, що ця вимога породжує дискримінацію незаміжніх осіб віком до 35 років, які бажають придбати будинок у зазначених районах.

Загалом скаржнику відмовлено від придбання житла за визначеною схемою, оскільки така пільгова політика була прийнята у контекст політики відновлення сільських районів $з$ метою створення передумов для збереження дійсного населеного пункту та регіону. Уповноважений орган при проведенні розслідування погодив, що зазначені Схеми матимуть корисні результати для малих громад та сприятимуть сталому розвитку сільської місцевості. Однак, такий висновок однозначно б не був вказаний, якщо 6 у вказаних Схемах не було передбачено "особливих випадків" (до них належать широкий перелік осіб, у тому числі різного віку).

У цьому контексті уповноважений орган Кіпру дійшов висновку, що правова політика, котра виключає певну групу осіб за віком без будь-яких цілей або причин обгрунтування, вводить несправедливу та несумісну 3 принципами рівності політику. Проте розглядуваний резонансний казус не містив ознак дискримінації за віком, а відповідав цілям подолання стагнації та вимирання сільського населення, розвитку всіх регіонів та економічного процвітання країни.

Поряд із цим розглянемо інший казус пов'язаний також 3 політикою Кіпру. Кіпрський антидискримінаційний орган розглядав скаргу, подану від імені незрячої особи у віці 73 років проти рішення Ради Міністрів № 61.144 від 16.11.2004, у якому визначено 70-річний вік як максимальне вікове обмеження для надання фінансової допомоги для придбання автомобіля працездатною людиною. Згідно зі скаргою факт ліміту віку констатуе дискримінацію щодо них за віком. Слід обумовити причину такого вікового обмеження. Придбаний автомобіль може бути переданий іншій особі після закінчення п’ятирічного терміну його використання особою з інвалідністю. У випадку смерті пільговика, автомобіль передається спадкоємцям без відшкодування фінансової суми допомоги, що надається урядом. Вказана 70-ти річна вікова межа створена для убезпечення зловживання державними пільгами.

Проте в результаті розгляду нормотворної та правозастосовної практики доведено, що існування вказаної норми становлять чітку дискримінаційну основу, оскільки вказують на переваги за віком. Окрім того додано, що дискримінація має подвійний характер і переплітається 3 дискримінацією осіб 3 інвалідністю. Потреба в мобільності осіб 3 інвалідність визнається, навіть якщо особи самі не в змозі через свою недієздатність особисто користуватися їх автомобілем. Відповідальність за їх мобільність, як правило, здійснюється членами їхньої родини. Уповноважений 3 питань дискримінації Кіпру вказав, що придбання автомобіля є законним та обгрунтованим, оскільки передбачено необхідністю підтримувати інвалідів та поважати їх право за рівноправну участь у соціальному житті. Більше того, забезпечення зручностей для мобільності старшої групи сприяє підвищенню якості їх життя, захищаючи своє право на незалежне життя та запобігає явищам соціальної ізоляції. Засоби для мобільності інвалідів особи стають більш необхідними у випадках людей похилого віку. Отож констатовано різне ставлення до осіб до 70 та після 70 років, що слід визнати політикою дискримінації. Окрім того, не було додано жодних розумних винятків 3 цього правила, що так само вказує на суворі аспекти правової дискримінації.

Висловлено припущення, що конкретні положення визначеної норми повинні бути переглянуті у світлі причин та фактів, викладених компетентними інстанціями розгляду [6, р.38].

Звертаємо Увагу, що більшість Уповноважених з прав людини акцентує увагу на тому, що проблеми дискримінації за віком стосуються людей літнього віку. Зокрема, Омбудсмен Республіки Чехії в річному звіті констатував, що за фактом дискримінації за віком звертаються особи зазвичай більше 60 років і всі питання зводяться до пенсійних виплат та проблем із шумоізоляцією (близько 2 тис. справ на рік) [7]. Проте є доволі 


\section{Теорія, історія держави і права, конституційне право}

цікаві казуси. Один з них стосується права особи похилого віку займати активну громадську позицію та реалізувати своє право на освіту та підвищення кваліфікації. Не всі люди бажають піти на пенсію та відпочити після досягнення пенсійного віку і звертаємо увагу на дискримінацію в разі порушення права реалізації будь з яких основоположних прав. . Деякі люди хочуть продовжувати працювати або навіть підвищують свою кваліфікацію. Один скаржник до Уповноваженого з прав продовжував працювати вчителем і після досягнення пенсійного віку. Однак роботодавець відмовився надати їй навчальну відпустку, до якої вона, як педагогічний працівник, мала статутне право. Роботодавець посилався на внутрішнє правове регулювання школи, що виключало одержувачів пенсії за віком за умови здобуття нових знань.

Справа не розглядалася по суті в судовому порядку, проте медіаційними процедурами роботодавець і скаржник погодили цю ситуацію на користь вчительки. Окрім того Омбутсмен зазначив, що справа має всі ознаки дискримінації.

\section{Висновок}

Дискримінація за віком часто не є в переліку основних нормативних ознак, проте нині вона займає якщо не перше місце, то входить до трійки лідерів за дискримінаційними ознаками. Проблема такого виду дискримінації має подвійний характер: іï або не помічають, вважаючи вказане нормальним, гуманним, життєвим розвитком подій; або навпаки виокремлюють їі з іншими видами дискримінації, зокрема расовою, статевою та іншими.

Стереотипи - це соціальні спільні пізнання та упереджені погляди та переконання, які не грунтуються на добре встановлених фактах. Вікові стереотипи можуть впливати на прийняття рішень, оцінки та поведінку членів організації та перешкоджати обробці нової інформації, що суперечить цим помилковим переконанням. Таким чином, вікові стереотипи можуть спричинити дискримінаційну поведінку. Стереотипи за віком є особливо разючі та дискримінаційні. Стара людина -це завжди хвора, потребуюча ува- ги та допомоги особа, яка витрачає соціальні кошти з державного бюджету.

Розгляд правової політики низки розвинених держав (зокрема Кіпру та Чехії) вказують на наявність суттєвих прогалин у правовому регулюванні, які подекуди виправдовуються фінансовою, правовою, соціальною та іншими видами політики.

Доведено, що найбільшою проблемою дискримінації за віком зазнають особи вікової категорії поза 60 років, та зазвичай вони стосуються трудового та цивільно-пенсійного характеру. Проте такий підхід суперечить принципу гуманності та рівності всіх осіб, тому забезпечення права на освіту, вільний розвиток, комунікацію, мобільність та інші перераховані казуси свідчать про потребу додаткового юридичного аналізу проблематики.

\section{Аітература}

1. Жаровська І. М. Генезис ідеї відкритості влади. Форум права. 2009. № 3. С. 242246.

2. Christian J., Rhiannon T., Holt N., Larkin M., Howard Cotler J. Does intergenerational contact reduce ageism? When and how contact interventions actually work? Journal of Art and Humanities. 2014. № 3. P. 1-5.

3. Maner U. Predictors of Ageist Attitudes of Turkish EMU Undergraduate Students. Submitted to the Institute of Graduate Studies and Research in Partial Fulfilment of Requirements of the Degree of Master of Science in Developmental Psychology. Unpublished Master's thesis, Eastern Mediterranean University, Famagusta, North Cyprus. 2016.

4. Hagestad G., and Peter U. The Social Separation of Old Young: A Root of Ageism. Journal of Social Issues. 2005. № 61. P. 343-360.

5. Butler R. Thoughts on aging. American Journal of Psychiatry. 1978. № 135.P. 14-16.

6. The second Annual Report of the Cyprus Anti-Discrimination Body. 42 p. URL: www.theioi.org

7. Czech Republic: Annual Rport on the Protection against Discrimination 2018 URL: https://equineteurope.org/2019/czechrepublic-annual-report-on-the-protectionagainst-discrimination-2018/ 


\section{АНОТАЦІЯ}

Дискриміначія за віком часто не є в переліку основних нормативних ознак, проте нині воно займає якщо не перше місце, то входить до трійки лідерів за дискримінаційними ознаками. Проблема такого виду дискримінаціӥ має подвійний характер: їі або не помічають, вважаючи вказане нормальним, гуманним, життевим розвитком подій; або навпаки виокремлюють ї̈ з іншими видами дискримінації, зокрема расовою, статевою та іниими.

Стереотипи - изе сочіальні спільні пізнання та упереджені погляди та переконання, які не грунтуються на добре встановлених фактах. Вікові стереотипи можуть впливати на прийняття рішень, оцінки та поведінку иленів організаиї та перешкоджати обробиі нової інбормачій, що суперечить ичм помилковим переконанням. Таким иином, вікові стереотипи можуть спричинити дискримінаційну поведінку. Стереотипи за віком є особливо разючі та дискриміначійні. Стара людина -це завжди хвора, потребуюча уваги та допомоги особа, яка витрачає соиіальні кошти з державного бюджету.

Розгляд правової політики низки розвинених держав (зокрема Кіпру та Чехії) вказує на наявність суттевих прогалин у правовому регулюванні, які подекуди виправдовуються фінансовою, правовою, сочіальною та іншими видами політики.

Доведено, що найбільшою проблемою дискримінаціӥ за віком зазнають особи вікової категорій поза 60 років, та зазвичай вони стосуються трудового та ицивільно-пенсійного характеру. Проте такий підхід суперечить приниипу гуманності та рівності всіх осіб, тому забезпечення права на освіту, вільний розвиток, комунікацію, мобільність та інші перераховані казуси свідчать про потребу додаткового юридичного аналізу проблематики.

Ключові слова: дискримінація, дискримінація за віком, стереотип, Уповноважений 3 прав людини. ейджизм. особи літнього віку.
AGE DISCRIMINATION (ON THE EXAMPLE OF EUROPEAN UNION CASES)

Age discrimination is often not on the list of the main normative features, but now it is, if not on the first place, then one of the three leaders on discriminatory features. The problem of this type of discrimination has a twofold nature: it is either not noticed, considering this as normal, humane, vital development of the life; or on the contrary, they distinguish it from other types of discrimination, including racial, sexual and other.

Stereotypes are social shared cognitions, prejudices and beliefs that are not based on well-established facts. Age stereotypes can influence the decisions, evaluations and behaviors of members of the organization and prevent the processing of new information, which contradicts these misconceptions. Thus, age stereotypes can lead to discriminatory behavior. Age stereotypes are particularly striking and discriminatory. An old person is always a sick person who needs attention and help, who spends social funds from the state budget.

Consideration of the legal policy of a number of developed countries (including Cyprus and the Czech Republic) indicates the existence of significant gaps in legal regulation, which are sometimes justified by financial, legal, social and other types of policy.

It has been proven that the greatest problem of age discrimination is experienced by persons over the age of 60 , and they usually relate to employment and civil pensions. However, this approach contradicts the principle of humanity and equality of all persons, so ensuring the right to education, free development, communication, mobility and other listed cases indicate the need for additional legal analysis of the issue.

Keywords: discrimination, age discrimination, stereotype, Commissioner for Human Rights, ageism, elderly people. 